\title{
Production of piglets as related to slaughter and growth traits
}

\section{MATTI PUONTI}

The Finnish Animal Breeding Association, P.O. Box 40, SF-01301 Vantaa 30 (Finland)

\footnotetext{
Abstract. The relations between sows production of piglets and their own on-farm testing results as well as their sibs results are analysed. The study is based on actual data from 248 normal pig farms, 3746 sows and 5195 litters.

A rapid growth rate seems to be correlated to early maturity by young sows. A favourable genetic relationship between farrowing age and litter size of the gilt was foud. Farrowing interval and litter size showed a positive phenotypic correlation. Sows lean in carcase had a higher farrowing age than other sows. Other carcase characteristics were not correlated to fertility traits. Breeding for fertility is possible by pigs without losses in other traits.
}

\section{Introduction}

The efficiency of pigmeat production is based on a high fertility of sows. The heritability of fertility is lower than of other traits in pigs. Heritability estimates, found in different investigations are ranging from 0.1 to 0.18 (CHRISTENSEN 1983).

The slight attention paid to the improvement of fertility characteristics in breeding programmes is most likely due to the low heritability of these traits. The high influence of environment has led to an improvement of management factors rather than genetic ones in pigs.

The pig breeding programme (Herd book rules) used in Finland has minimum requirements for litter size. To be entered in the herdbook class a sow must have at least 9 piglets per litter alive at 3 weeks.

The pig breeders have been suspicious of a negative influence of production and carcase traits on the fertility of pigs. The objective of this study was to examine whether the breeding goals are undesirably correlated to fertility traits. 


\section{Material and methods}

In this study statistics from the official pig production control was used. The material is principally from 1982, when a new computer system was introduced. Sow data from $284 \mathrm{pig}$ farms were examined. The study involves both breeding herds and integrated units. Of the litters studied $53 \%$ were Large White, $34 \%$ Landrace and $13 \%$ crossings.

Only sows with registered first litter data were used. Also second litter data if already registered, were examined from the same sows.

The performance test scores are identical to those used in the Finnish Animal Breeding Association's regular on-farm testing scheme.

The progeny test results are based on testing progeny groups of boars in testing stations.

The size of the material and averages for examined characteristics are shown in table 1,2 and 3.

\section{Results and discussion}

According to the phenotypic correlations farrowing age had only a slight influence on litter size (table 4). The positive relationship between farrowing age and litter size seems logical as older gilts are likely to be more developed

Table 1. Fertility results of the first and second litter of sows.

\begin{tabular}{|c|c|c|c|}
\hline Trait & $\mathrm{N}$ & $\overline{\mathbf{x}}$ & s \\
\hline \multicolumn{4}{|l|}{ Gilts } \\
\hline Farrowing age, days & 3746 & 366 & 37 \\
\hline \multicolumn{4}{|l|}{ Litter size } \\
\hline at birth & 3746 & 10.6 & 2.8 \\
\hline at 3 weeks age & 3413 & 9.0 & 2.7 \\
\hline at weaning & 3090 & 8.9 & 2.7 \\
\hline \multicolumn{4}{|c|}{ Days between 1st and 2nd } \\
\hline farrowing & 1449 & 178 & 27 \\
\hline \multicolumn{4}{|l|}{ Second litter } \\
\hline \multicolumn{4}{|l|}{ Litter size } \\
\hline at birth & 1449 & 11.9 & 3.1 \\
\hline at 3 weeks age & 1339 & 10.2 & 2.8 \\
\hline at weaning & 1182 & 9.9 & 2.7 \\
\hline
\end{tabular}

Table 2. Performance results of sows on farm test.

\begin{tabular}{lrrr}
\hline Trait & $\mathrm{N}$ & $\overline{\mathbf{x}}$ & $\mathrm{s}$ \\
\hline Fat points & 3613 & 53.7 & 3.3 \\
Growth points & 3613 & 53.7 & 3.3 \\
T-index & 3613 & 107.5 & 4.2 \\
\hline
\end{tabular}


Table 3. Progeny test results of sires of sows.

\begin{tabular}{lccc}
\hline Trait & $\mathrm{N}$ & $\overline{\mathrm{x}}$ & $\mathrm{s}$ \\
\hline Side fat, mm & 2632 & 15.2 & 1.5 \\
Carcase length, cm & 2632 & 96.0 & 7.3 \\
Index components & & & \\
$\quad$ production traits & 2632 & 0.8 & 2.0 \\
$\quad$ carcase traits & 2632 & 2.2 & 3.2 \\
K-index & 2632 & 6.1 & 4.2 \\
\hline
\end{tabular}

Table 4. Phenotypic correlations between reproduction and performance traits.

\begin{tabular}{l|rrrrrr} 
& 1. & 2. & 3. & 4. & 5. & 6. \\
\hline 1. Farrowing age & & & & & & \\
2. Farrowing interval & 0.06 & & & & & \\
3. Litter size at birth, gilts & 0.07 & 0.08 & & & & \\
4. Litter size at birth, 2nd litter & 0.04 & 0.13 & 0.19 & & & \\
$\quad$ On farm test & & & & & & \\
5. Fat points & 0.08 & 0.11 & -0.01 & -0.01 & & \\
6. Growth points & -0.22 & -0.04 & 0.11 & 0.05 & -0.17 & \\
7. T-index & -0.10 & 0.06 & 0.08 & 0.03 & 0.65 & 0.63
\end{tabular}

physiologically than younger gilts. However, the corresponding genetical correlation between age and first litter was -0.35 . This indicates that the same genes are affecting the various fertility factors in the same way.

Big first litters caused a slight lengthening of the farrowing interval and the second litter born after a lengthened interval was bigger on an average than those born after a shorter farrowing interval.

The size of first and second litter showed a positive phenotypic $(0.19)$ and genetic (0.56) correlation. JOHANSSON (1983) found similar relationships in Swedish material from breeding herds.

The sow's own growth rate was positively correlated to farrowing age and litter size as well. The genetic correlation between growth rate and age at farrowing was -0.69 and the correlation between growth rate measurements and size of first litter was 0.47 . These results confirm those reported by JOHANSSON and KENNEDY (1982) from Swedish pig breeds. In their data a positive correlation was found between on-farm testing age and farrowing age ( 0.09 by Landrace and 0.27 by Large White).

MORRIS (1975) found that the feed conversion rate and the growth rate were positively correlated to litter size and weight, whereas a negative correlation was obtained between slaughter losses and litter size.

The fat thickness showed only a slight relation to the fertility traits. On the other hand, JOHANSSON and KENNEDY (1982) reported a strong unfavourable correlation between fat thickness and fertility. According to JOHANSSON (1983) the sexual maturity by pigs is connected to the fat content of body. 
Contradictory to above mentioned findings, MORRIS (1975) obtained a positive correlation between litter size and meat in carcase.

The T-index is a sum of the fat and daily gain measurements.It is used in Finland by individual selection of sows and boars. The T-index is positively related to fertility. Its genetic correlations to farrowing age was -0.64 , to size of first litter 0.33 and size of second litter 0.37.

The progeny test result of the sow's sire did not affect the fertility traits of the daughters (table 5). Only carcase length and fat thickness showed a positive relationship to farrowing age. BERESKIN and FROBISH (1982) have found a negative correlation between fertility and carcase lean content. They suggest that both sow productivity and carcase and performance traits need to be included in testing programmes for all breeds. Also HILL (1982) recommends use of litter size evaluation in the performance testing scheme.

According to WEBB et al. (1982) stress susceptibility has a negative influence on fertility and farrowing traits. Elimination of the halothane gene by testing in breeds where it is at high frequency could lead to improvements in litter size (HILL 1982).

The results found in this study indicate that progress can be made in fertility traits without losses in growth performance and carcase traits.

Table 5. Phenotypic correlations between sow reproduction and progeny testing results of sire of sow.

\begin{tabular}{l|ccccr}
\multicolumn{1}{c}{$\begin{array}{c}\text { progeny test of sire } \\
\text { of sow }\end{array}$} & $\begin{array}{c}\text { production } \\
\text { index } \\
\text { reproduction } \\
\text { traits of sow }\end{array}$ & $\begin{array}{c}\text { carcase } \\
\text { index } \\
\text { and daily gain) }\end{array}$ & $\begin{array}{r}\mathrm{K} \text {-index } \\
\text { and }\end{array}$ & $\begin{array}{c}\text { carcase } \\
\text { length }\end{array}$ & $\begin{array}{c}\text { side } \\
\text { fat }\end{array}$ \\
\hline Farrowing age & -0.02 & -0.03 & -0.03 & -0.12 & 0.11 \\
Farrowing interval & 0.04 & 0.09 & 0.09 & 0.00 & -0.05 \\
Litter size at birth, gilts & 0.02 & 0.02 & 0.02 & 0.03 & -0.01 \\
Litter size at birth, 2nd litters & 0.00 & 0.04 & 0.04 & 0.02 & -0.01
\end{tabular}

Acknowledgements: The author wishes to thank Ms. Anneli Koskinen for assistance of data collection.

This work has been supported by grants from the Ministry of Agriculture and Forestry in Finland.

\section{References}

BERESKIN, B. \& FROBISH, L. T. 1982. Carcass and related traits in duroc and yorkshire pigs selected for sow productivity and pig performance. J. Anim. Sci. 55: 554-564.

CHRISTENSEN, A. 1983. Muligheter for å inkludere frugtbarheten i avlsindeksen. NJF Seminarium nr 51: 6, 1-16. Sånga-Säby.

HILL, W. G. 1982. Genetic improvement of reproductive performance in pigs. Pig News Inf. 3: 137-141. JOHANSSON, K. 1983. Genetiska förutsättningar för fruktsamhetsurval hos svin. NJF Seminarium nr 51: 5, 1-8. Sånga-Säby.

JOHANSSON, K. \& KENNEDY, B. W. 1982. Genetic and phenotypic relationships of performance test measurements with fertility in Swedish landrace and yorkshire sows. Acta Agric. Scand. 33: 195199. 
MORRIS, C. A. 1975. Genetic relationships of reproduction with growth and with carcass traits in british pigs. Anim. Prod. 20: 31-44.

WEBB, A. J., CARDEN, A. E., SMITH, C. \& IMLAH, P. 1982. Porcine stress syndrome in pig breeding. 2nd World Congr. Genet. Appl. Livestock Production. Madrid. p. 588-608.

Ms received December 13, 1983

SELOSTUS

Porsastuotoksen yhteydestä teuras- ja kasvuominaisuuksiin

Matti Puonti

Suomen Kotieläinjalostusyhdistys, Sikatalousosasto. 01301 Vantaa.

Tutkimuksessa selvitettiin emakoiden porsastuotantotulosten yhteyttä emakon omiin tilatestituloksiin ja sisartuloksiin. Aineistona oli käytännön sikaloiden tiedot yhteensä 284 sikalasta, 3746 emakosta ja 5195 pahnueesta.

Havaittiin, että nopea kasvu merkitsi nuorille emakoille aikaista hedelmällisyyttä. Emakon porsimisikä ja pahnuekoko olivat perinnöllisesti suotuisasti toisiinsa liittyneitä. Porsimisvälillä ja pahnuekoolla oli positiivinen fenotyyppinen korrelaatio. Ohutsilavaisilla emakoilla oli muita emakoita suurempi porsimisikä. Muilla teurasominaisuuksilla ei ollut yhteyttä hedelmällisyysominaisuuksiin.

Pääteltiin, että hedelmällisyyden jalostaminen on sioilla mahdollista ilman, että samalla huononnettaisiin muita ominaisuuksia. 